Research

Open Access

\title{
Small-volume resuscitation with hyperoncotic albumin: a systematic review of randomized clinical trials
}

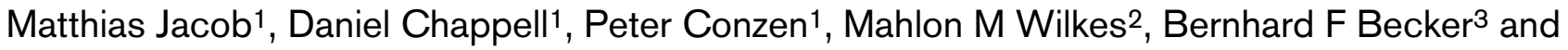 \\ Markus Rehm ${ }^{1}$
}

\author{
${ }^{1}$ Klinik für Anästhesiologie, Ludwig-Maximilians-Universität, Klinikum Grosshadern, Nussbaumstrasse 20, D-80336 Munich, Germany \\ ${ }^{2}$ Hygeia Associates, 17988 Brewer Road, Grass Valley, California 95949, USA \\ ${ }^{3}$ Physiologisches Institut - Vegetative Physiologie, Ludwig-Maximilians-Universität, Schillerstrasse 44, D-80336 Munich, Germany \\ Corresponding author: Matthias Jacob, matthias.jacob@med.uni-muenchen.de
}

Received: 30 Oct 2007 Revisions requested: 11 Dec 2007 Revisions received: 16 Feb 2008 Accepted: 4 Mar 2008 Published: 4 Mar 2008

Critical Care 2008, 12:R34 (doi:10.1186/cc6812)

This article is online at: http://ccforum.com/content/12/2/R34

(c) 2008 Jacob et al.; licensee BioMed Central Ltd.

This is an open access article distributed under the terms of the Creative Commons Attribution License (http://creativecommons.org/licenses/by/2.0), which permits unrestricted use, distribution, and reproduction in any medium, provided the original work is properly cited.

\begin{abstract}
Background Small-volume resuscitation can rapidly correct hypovolemia. Hyperoncotic albumin solutions, long in clinical use, are suitable for small-volume resuscitation; however, their clinical benefits remain uncertain.

Methods Randomized clinical trials comparing hyperoncotic albumin with a control regimen for volume expansion were sought by multiple methods, including computer searches of bibliographic databases, perusal of reference lists, and manual searching. Major findings were qualitatively summarized. In addition, a quantitative meta-analysis was performed on available survival data.
\end{abstract}

Results In all, 25 randomized clinical trials with a total of 1,485 patients were included. In surgery, hyperoncotic albumin preserved renal function and reduced intestinal edema compared with control fluids. In trauma and sepsis, cardiac index and oxygenation were higher after administration of hydroxyethyl starch than hyperoncotic albumin. Improved treatment response and renal function, shorter hospital stay and lower costs of care were reported in patients with liver disease receiving hyperoncotic albumin. Edema and morbidity were decreased in high-risk neonates after hyperoncotic albumin administration. Disability was reduced by therapy with hyperoncotic albumin in brain injury. There was no evidence of deleterious effects attributable to hyperoncotic albumin. Survival was unaffected by hyperoncotic albumin (pooled relative risk, $0.95 ; 95 \%$ confidence interval 0.78 to 1.17 ).

Conclusion In some clinical indications, randomized trial evidence has suggested certain benefits of hyperoncotic albumin such as reductions in morbidity, renal impairment and edema. However, further clinical trials are needed, particularly in surgery, trauma and sepsis.

\section{Introduction}

The advantages of small-volume resuscitation in rapidly correcting hypovolemia and interrupting the pathological processes leading to multi-organ failure and other poor outcomes are well recognized [1]. The use of hyperosmolar solutions containing artificial colloid for small-volume resuscitation has been described previously [2]. Another fluid type suitable for small-volume resuscitation is hyperoncotic (20 to $25 \%$ ) albumin. Indeed, the original form of albumin developed in the early 1940s for resuscitation of combat casualties was a hyperoncotic $25 \%$ solution, designed for portability [3]. Currently, 4 to $5 \%$ albumin solutions are also widely employed for volume expansion. Whereas 4 to $5 \%$ albumin expands intravascular volume by approximately $80 \%$ of the administered volume [4$15]$, the corresponding effect of $20 \%$ albumin averages $210 \%$ [4,16-18] and 25\% albumin 260\% [4,19-21]. Consequently, hyperoncotic albumin can accomplish the same volume expansion effect as 4 to $5 \%$ albumin using only roughly one-third of

$\overline{\mathrm{ANP}}=$ atrial natriuretic peptide; $\mathrm{APACHE}=$ Acute Physiology and Chronic Health Evaluation; apt $=$ activated partial thromboplastin time; $\mathrm{Cl}=\mathrm{con}-$ fidence interval; $\mathrm{COP}=$ colloid oncotic pressure; $\mathrm{CVP}=$ central venous pressure; $\mathrm{DO}_{2} \mathrm{l}=$ oxygen delivery index; $\mathrm{HES}=$ hydroxyethyl starch; $I \mathrm{IQR}=$ interquartile range; ISS $=$ injury severity score; $\mathrm{MAP}=$ mean arterial pressure; $\mathrm{PaO}_{2} / \mathrm{FiO}_{2}=$ ratio of partial pressure of arterial oxygen to fraction of inspired oxygen; $\mathrm{PCWP}=$ pulmonary capillary wedge pressure; $\mathrm{pH}_{\mathrm{i}}=$ gastric intramucosal $\mathrm{pH} ; \mathrm{PT}=$ prothrombin time; $\mathrm{RL}=\mathrm{Ringer}$ 's lactate; $\mathrm{RR}=$ relative risk; RVEF = right ventricular ejection fraction; sELAM-1 = soluble endothelial leucocyte adhesion molecule- $1 ;$ sICAM-1= soluble intercellular adhesion molecule-1; SVRI = systemic vascular resistance index; $\mathrm{VO}_{2} \mathrm{I}=$ oxygen consumption index. 
the administered volume, thus diminishing the time needed to attain the desired expansion of the intravascular space. The disproportion in administered volume is far greater vs crystalloid, since, for example, the required volume of Ringer's lactate (RL) was fourfold that of $5 \%$ albumin to achieve the same hemodynamic endpoints in a randomized trial of patients with multiple trauma and shock [22]. Furthermore, the effect of hyperoncotic albumin is relatively long lasting, with at least two-thirds of the initial volume expansion effect persisting at $6-8 \mathrm{~h}$ after infusion $[19,21]$.

Hyperoncotic albumin also possesses the capacity to draw interstitial fluid into the intravascular space, in accord with the Starling fluid equilibrium equation [23]. Thus, undesirable edema may be reduced [24].

Nonetheless, it has remained unclear whether the properties of hyperoncotic albumin can translate into demonstrable clinical benefits. The only large-scale randomized trial of outcomes after albumin administration, the Saline versus Albumin Fluid Evaluation (SAFE) trial [25], compared 4\% albumin with normal saline for management of hypovolemia, and no difference in survival was detected. Systematic reviews of mortality, morbidity and other endpoints thus far have not discriminated between 4 to $5 \%$ and 20 to $25 \%$ solutions of albumin [26-30]. The multi-center non-randomized observational Sepsis Occurrence in Acutely ill Patients (SOAP) study also did not differentiate between types of albumin solutions [31].

The present systematic review of randomized clinical trials is focused exclusively on hyperoncotic albumin solutions. A qualitative critical appraisal of the randomized trial evidence is presented. Additionally, a quantitative meta-analysis of survival after hyperoncotic albumin administration is reported.

\section{Methods \\ Objectives}

This systematic review of randomized clinical trials was undertaken to determine whether hyperoncotic albumin consistently differs from control regimens in its effects upon clinically relevant endpoints such as morbidity, major organ function, length of stay and cost of care in acutely ill patients. Such endpoints are often not defined, assessed and reported in a consistent and standardized manner, so qualitative summarization is more appropriate than quantitative combination of results across trials. A secondary objective was to evaluate the effect of hyperoncotic albumin on survival by quantitative meta-analysis.

\section{Inclusion criteria}

All randomized clinical trials comparing hyperoncotic albumin with a control regimen for volume expansion in acutely ill patients were eligible for inclusion. Both parallel-group and crossover study designs were acceptable. Randomized trials focusing on other uses of albumin such as treatment of hyperbilirubinemia, extracorporeal albumin dialysis or prevention of ovarian hyperstimulation syndrome were excluded. Also excluded were randomized trials of albumin as an adjunct to paracentesis or for correction of hypoalbuminemia, both of which have been evaluated in previous systematic reviews $[28,29]$.

\section{Identification of studies}

Randomized clinical trials fulfilling the inclusion criteria for the systematic review were identified by multiple methods, including computer searches of the Medline and EMBASE bibliographic databases and the Cochrane Library. Search terms included hyperoncotic albumin, resuscitation, hypovolemia, surgery, trauma, sepsis, liver diseases, intensive care, neonatal, brain injuries, nephrotic syndrome and randomized controlled trials. Studies were also sought through examination of reference lists and manual searching of Index Medicus and specialty journals. No restrictions on time period or language of publication were applied.

\section{Data extraction}

Data on numbers of patients randomized, clinical indication, hyperoncotic albumin and control regimen, major findings and deaths were extracted from the randomized clinical trial reports and used to populate a relational database. The participating investigators, time periods and study subject characteristics were closely examined to avoid inclusion of duplicate datasets appearing in multiple publications and to ensure the most complete possible dataset. Deaths were recorded on an intent-to-treat basis. Unpublished survival data and clarification regarding study design features were sought as needed via direct inquiries with the randomized trial investigators.

\section{Quality assessment}

Trial quality was evaluated by the criteria of blinding and allocation concealment. On the basis of the procedures employed in the study, allocation concealment was classified as adequate, inadequate or unclear [32].

\section{Statistical analysis}

$\mathrm{R}$ version 2.4.1 (The R Foundation for Statistical Computing, Vienna, Austria), Stata 9.1 (Stata Corp., College Station, TX, USA) and SPSS 11.5 (SPSS Inc., Chicago, IL, USA) statistical software was used for analyses. The attributes of the included trials were summarized by descriptive statistics, i.e., the median and interquartile range (IOR).

The primary endpoint for the quantitative meta-analysis of survival was the relative risk (RR) of death. The $95 \%$ confidence interval $(\mathrm{Cl})$ of RR was also calculated. RR can only be calculated when at least one death has been observed; hence, trials with no deaths did not enter the survival meta-analysis. Deaths in crossover trials were also excluded from the meta-analysis, since in such trials the same patients are exposed to both the albumin and control regimens and the attributability of death to one regimen or the other is uncertain. Pooled RR was 
estimated under a fixed-effects model. Publication bias was assessed by the method of Egger et al. [34]. The statistical power of the meta-analysis was calculated as $1-\Phi\left(C_{\alpha / 2}-\lambda\right)$ $+\Phi\left(-\mathrm{C}_{\alpha / 2}-\lambda\right)$, where $\Phi=$ the standard normal cumulative distribution function, $\mathrm{C}_{\alpha / 2}=$ the standard normal critical value for a two-sided test at the $0.05 \alpha$ level, and $\lambda=(\operatorname{In}($ pooled RR) 1)/(pooled standard error) [34].

\section{Results}

\section{Included trials}

A total of 25 randomized clinical trials [35-59] with an aggregate of 1,485 patients were included in the review (Figure 1). The median number of patients per trial was 30 (IOR, 18-58). In all, 21 of the trials (84\%) had been published from 1990 onwards. Parallel groups were compared in 21 trials, and a crossover design was employed in the remaining 4 . The control regimen consisted of another colloid, predominantly hydroxyethyl starch (HES), in nine trials (36\%), crystalloid in four $(16 \%)$, no albumin in six (24\%) and lower-dose albumin in one (4\%). Two separate control regimens composed of another colloid and either crystalloid or no albumin were administered in five trials (20\%).

In five trials, the effects of hyperoncotic albumin were separately investigated among patients with either trauma or sepsis $[44-46,48,49]$. Randomized comparisons involving surgery and trauma are summarized in Table 1, sepsis in Table 2 and other indications in Table 3. The other indications were comprised of liver disease, high-risk neonates, brain injury, intradialytic hypotension and nephrotic syndrome. The trials of highrisk neonates involved premature infants with risk factors such as low birth weight, respiratory dysfunction or brain injury.
Evaluated study endpoints included survival in three trials $[40,51,53]$, morbidity in six $[35,40,43,53,56,58]$, major organ function in six $[41,42,49,56,58,59]$, length of stay in two $[51,56]$, and costs of care in one [51]. Among additional endpoints assessed were hemodynamics in seven trials $[45,48,49,52,54,55,59]$, major organ edema in two [39,56], whole body edema in two [38,42], coagulation function in four $[39,44,46,49]$, colloid oncotic pressure (COP) in two [36,37], diuretic responsiveness in two [50,57], and inflammatory markers in one [47].

\section{Trial quality}

Four trials (16\%) were blinded $[41,50,53,56]$, and the remainder unblinded. Allocation concealment was adequate in four trials $(16 \%)[50,51,53,58]$ and inadequate or unclear in the rest.

\section{Surgery}

Based on randomized clinical trial data from surgical patients summarized in Table 1, hyperoncotic albumin more effectively maintained colloid oncotic pressure than control regimens in both cardiac [37] and non-cardiac surgery [36]. Compared with HES, hyperoncotic albumin better preserved renal function [41] and coagulation [39]. A greater increase in cardiac output was demonstrated after administration of hyperoncotic albumin than saline to the same right atrial pressure target [52]. Hyperoncotic albumin was superior to both HES and crystalloid in preventing intestinal edema during abdominal surgery [39].

Figure 1

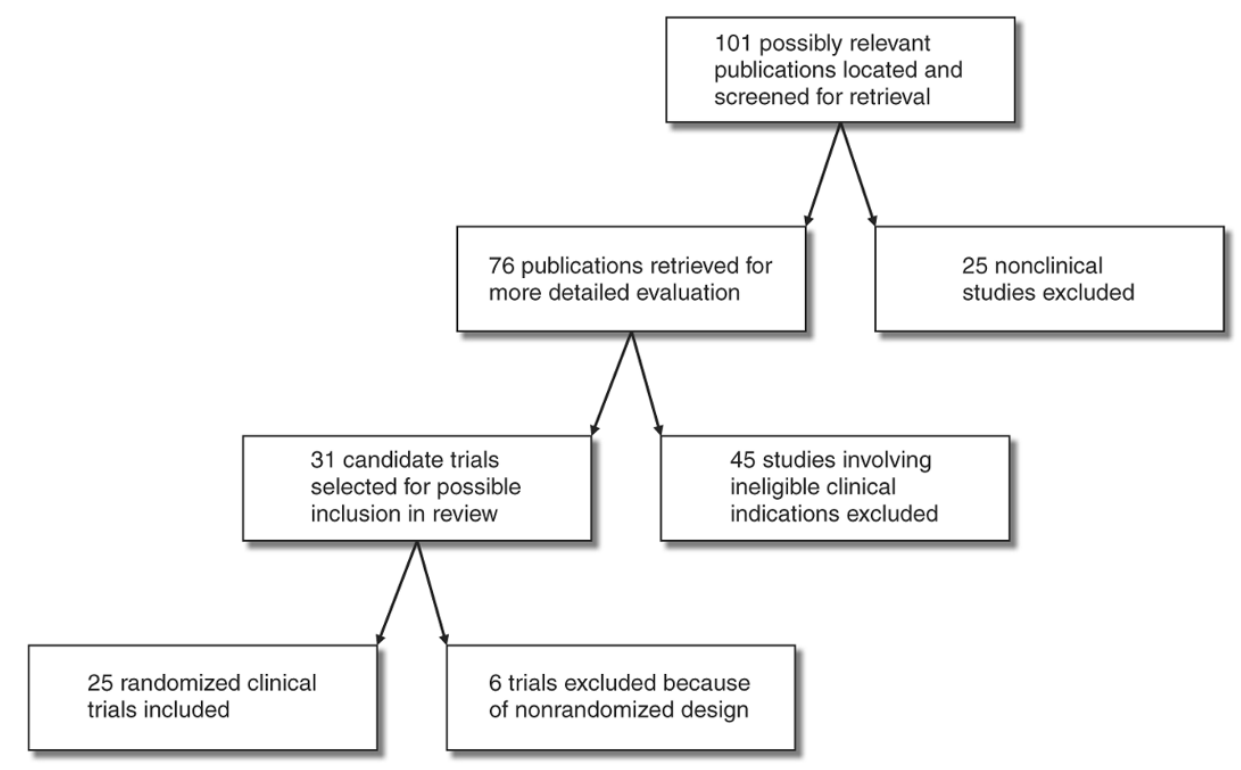

Selection process for randomized clinical trials. 
Table 1

Randomized clinical trials of hyperoncotic albumin in surgery and trauma

\begin{tabular}{|c|c|c|c|c|}
\hline Trial & $\mathbf{n}$ & Indication & Regimen & Results \\
\hline \multicolumn{5}{|l|}{ Cardiac surgery } \\
\hline Boldt et al., 1986 [37] & 55 & $\begin{array}{l}\text { Coronary artery bypass } \\
\text { grafting }\end{array}$ & $\begin{array}{l}300 \mathrm{ml} 20 \% \text { albumin intraoperatively } \\
\text { after bypass vs } 500 \mathrm{ml} 3 \% \text { HES } 200 / \\
0.5 \text { vs } 500 \mathrm{ml} 3.5 \% \text { gelatin vs no } \\
\text { additional volume }\end{array}$ & $\begin{array}{l}\text { Post-bypass COP rebound greater in } \\
\text { albumin than other groups }(p<0.05)\end{array}$ \\
\hline Boldt et al., 1993 [41] & 30 & $\begin{array}{l}\text { Cardiac defect repair in } \\
\text { children }<3 \text { years old }\end{array}$ & $\begin{array}{l}20 \% \text { albumin vs } 6 \% \text { HES } 200 / 0.5 \text { to } \\
\text { stabilize hemodynamics before bypass }\end{array}$ & $\begin{array}{l}\text { On-bypass urine output in HES group } \\
\text { lower by } 57 \% \text { than that of albumin } \\
\text { group }(p<0.05)\end{array}$ \\
\hline $\begin{array}{l}\text { Magder and Lagonidis, } \\
1999[52]\end{array}$ & 28 & $\begin{array}{l}\text { Stable patients after } \\
\text { cardiac bypass surgery }\end{array}$ & $\begin{array}{l}100 \mathrm{ml} 25 \% \text { albumin vs saline to } \\
\text { increase right atrial pressure by } 2 \mathrm{~mm} \\
\mathrm{Hg}\end{array}$ & $\begin{array}{l}\text { Greater increase in cardiac output } \\
\text { among hyperoncotic albumin } \\
\text { recipients, suggesting an inotropic } \\
\text { effect }\end{array}$ \\
\hline \multicolumn{5}{|l|}{ Non-cardiac surgery } \\
\hline $\begin{array}{l}\text { Zetterström and } \\
\text { Hedstrand, } 1981 \text { [36] }\end{array}$ & 30 & $\begin{array}{l}\text { Elective major abdominal } \\
\text { surgery }\end{array}$ & $\begin{array}{l}300-400 \mathrm{ml} 20 \% \text { albumin on } \\
\text { operation day, } 200 \mathrm{ml} \text { on next day and } \\
100 \mathrm{ml} / \text { day for subsequent } 3 \text { days vs } \\
\text { no albumin }\end{array}$ & $\begin{array}{l}\text { In albumin recipients COP significantly } \\
\text { closer to preoperative level on } \\
\text { postoperative days } 2-6\end{array}$ \\
\hline Prien et al., 1990 [39] & 18 & Abdominal surgery & $\begin{array}{l}20 \% \text { albumin vs } 10 \% \text { HES } 200 / 0.5 \text { vs } \\
\text { Ringer's lactate to maintain } \\
\text { preoperative CVP }\end{array}$ & $\begin{array}{l}\text { Significantly lower intraoperative } \\
\text { intestinal edema after albumin } \\
\text { compared with either HES or Ringer's } \\
\text { lactate; impaired coagulation in HES } \\
\text { recipients }\end{array}$ \\
\hline \multicolumn{5}{|l|}{ Trauma } \\
\hline Boldt et al., 1995 [44] & 30 & Trauma of ISS $>15$ & $\begin{array}{l}20 \% \text { albumin vs } 10 \% \text { HES } 200 / 0.5 \text { to } \\
12-16 \mathrm{~mm} \mathrm{Hg} \text { target CVP, PCWP or } \\
\text { both }\end{array}$ & $\begin{array}{l}\text { No between-group differences in daily } \\
\text { profiles of plasma thrombomodulin, } \\
\text { proteins } C \text { and } S \text { and thrombin- } \\
\text { antithrombin III }\end{array}$ \\
\hline Boldt et al., 1996 [45] & 30 & $\begin{array}{l}\text { Trauma of ISS between } 15 \\
\text { and } 30\end{array}$ & $\begin{array}{l}20 \% \text { albumin vs } 10 \% \text { HES } 200 / 0.5 \text { to } \\
12-18 \mathrm{~mm} \mathrm{Hg} \text { target PCWP }\end{array}$ & $\begin{array}{l}\text { HES } 200 / 0.5 \text { but not albumin } \\
\text { increased cardiac index, } \mathrm{PaO}_{2} / \mathrm{FiO}_{2} \text {, } \\
\mathrm{DO}_{2} \mathrm{I} \text { and } \mathrm{VO}_{2} \mathrm{I}(\mathrm{p}<0.05 \text { for all } \\
\text { comparisons) }\end{array}$ \\
\hline Boldt et al., 1996 [46] & 28 & Trauma of ISS $>15$ & $\begin{array}{l}20 \% \text { albumin vs } 10 \% \text { HES } 200 / 0.5 \text { to } \\
12-16 \mathrm{~mm} \text { Hg target CVP, PCWP or } \\
\text { both }\end{array}$ & $\begin{array}{l}\text { Maximum platelet aggregation } \\
\text { declined in both groups }(p<0.05)\end{array}$ \\
\hline Boldt et al., 1996 [48] & 28 & Trauma of ISS $>15$ & $\begin{array}{l}20 \% \text { albumin vs } 10 \% \text { HES } 200 / 0.5 \text { to } \\
10-15 \mathrm{~mm} \mathrm{Hg} \text { target PCWP }\end{array}$ & $\begin{array}{l}\text { Vasopressin decreased in HES } 200 / \\
0.5 \text { but not albumin group }(p<0.05)\end{array}$ \\
\hline Boldt et al., 1998 [49] & 150 & Trauma of ISS $>15$ & $\begin{array}{l}20 \% \text { albumin vs } 10 \% \text { HES } 200 / 0.5 \text { to } \\
12-15 \mathrm{~mm} \mathrm{Hg} \text { target PCWP }\end{array}$ & $\begin{array}{l}\mathrm{PaO}_{2} / \mathrm{FiO}_{2} \text { increased by } \mathrm{HES} 200 / 0.5 \\
\text { but not albumin }(\mathrm{p}<0.05) \text {; higher } \\
\text { cardiac index, } \mathrm{DO}_{2} \mathrm{I} \text { and } \mathrm{VO}_{2} \mathrm{I} \text { in } \mathrm{HES} \\
200 / 0.5 \text { group ( } \mathrm{p}<0.05 \text { for all } \\
\text { comparisons); no differences in } \\
\text { incidence of renal failure, platelet } \\
\text { count, } \mathrm{PT} \text { or aPTT }\end{array}$ \\
\hline
\end{tabular}

aPTT, activated partial thromboplastin time; COP, colloid oncotic pressure; CVP, central venous pressure; $\mathrm{DO}_{2} \mathrm{l}$, oxygen delivery index; $\mathrm{HES}_{\text {, }}$ hydroxyethyl starch; ISS, injury severity score; $\mathrm{PaO}_{2} / \mathrm{FiO}_{2}$, ratio of partial pressure of arterial oxygen to fraction of inspired oxygen; PCWP, pulmonary capillary wedge pressure; $\mathrm{PT}$, prothrombin time; $\mathrm{VO}_{2} \mathrm{l}$, oxygen consumption index.

\section{Trauma}

In contrast, among the five randomized comparisons in trauma described by Boldt et al. (Table 1) no apparent clinical advantages of hyperoncotic albumin over HES were apparent in three reports $[44,46,48]$. In the other two reports $[45,49]$, cardiac index and oxygenation were increased by HES relative to albumin.

\section{Liver disease}

In cirrhotic patients with refractory ascites (Table 3), hyperon-

\section{Sepsis}

Similarly, in sepsis (Table 2) higher cardiac index and oxygenation after HES than albumin administration were observed in several trials $[45,49,59]$. Additionally, HES maintained higher gastric intramucosal $\mathrm{pH}$ than hyperoncotic albumin in two trials $[45,48]$ and improved Acute Physiology and Chronic Health Evaluation II score in one [59].

cotic albumin increased the treatment response rate, shortened hospital stay and reduced costs of care [51]. In patients 
Table 2

Randomized clinical trials of hyperoncotic albumin in sepsis

\begin{tabular}{|c|c|c|c|c|}
\hline Trial & $\mathbf{n}$ & Indication & Regimen & Results \\
\hline Boldt et al., 1995 [44] & 30 & Sepsis after major surgery & $\begin{array}{l}20 \% \text { albumin vs } 10 \% \text { HES } \\
200 / 0.5 \text { to } 12-16 \mathrm{~mm} \mathrm{Hg} \\
\text { target CVP, PCWP or both }\end{array}$ & $\begin{array}{l}\text { Plasma thrombomodulin increased in albumin } \\
\text { group and remained unchanged in HES } 200 / 0.5 \\
\text { group }(p<0.05) ; \text { plasma protein } \mathrm{C} \text { among HES } \\
200 / 0.5 \text { recipients increased on days } 4 \text { and } 5 \\
\text { without corresponding change in albumin group ( } p \\
<0.05 \text { ) }\end{array}$ \\
\hline Boldt et al., 1996 [45] & 30 & $\begin{array}{l}\text { Sepsis secondary to major } \\
\text { general surgery }\end{array}$ & $\begin{array}{l}20 \% \text { albumin vs } 10 \% \text { HES } \\
200 / 0.5 \text { to } 12-18 \mathrm{~mm} \mathrm{Hg} \\
\text { target PCWP }\end{array}$ & $\begin{array}{l}\text { HES } 200 / 0.5 \text { but not albumin increased cardiac } \\
\text { index, RVEF, } \mathrm{PaO} / \mathrm{FiO}_{2}, \mathrm{DO}_{2} \mathrm{I} \text { and } \mathrm{VO}_{2} \text { and } \\
\text { decreased SVRI }(\mathrm{p}<0.05 \text { for all comparisons); } \\
\text { pH } \mathrm{H}_{\mathrm{i}} \text { decreased in albumin but not } \mathrm{HES} 200 / 0.5 \\
\text { group }(\mathrm{p}<0.05)\end{array}$ \\
\hline Boldt et al., 1996 [46] & 28 & Sepsis after major surgery & $\begin{array}{l}20 \% \text { albumin vs } 10 \% \mathrm{HES} \\
200 / 0.5 \text { to } 12-16 \mathrm{~mm} \mathrm{Hg} \\
\text { target CVP, PCWP or both }\end{array}$ & $\begin{array}{l}\text { Maximum platelet aggregation declined in both } \\
\text { groups }(p<0.05)\end{array}$ \\
\hline Boldt et al., 1996 [47] & 42 & $\begin{array}{l}\text { Sepsis secondary to major } \\
\text { surgery }\end{array}$ & $\begin{array}{l}20 \% \text { albumin vs } 6 \% \text { HES } \\
200 / 0.5 \text { vs pentoxyfylline } \\
(300 \mathrm{mg} \text { bolus plus } 1.4 \\
\mathrm{mg} / \mathrm{kg} / \mathrm{h} \text { continuous } \\
\text { infusion) }\end{array}$ & $\begin{array}{l}\text { Circulating sELAM- } 1 \text { and sICAM- } 1 \text { concentrations } \\
\text { reduced by HES } 200 / 0.5 \text { compared with albumin } \\
\text { ( } p<0.05 \text { for both comparisons) }\end{array}$ \\
\hline Boldt et al., 1996 [48] & 28 & $\begin{array}{l}\text { Sepsis secondary to major } \\
\text { surgery }\end{array}$ & $\begin{array}{l}20 \% \text { albumin vs } 10 \% \mathrm{HES} \\
200 / 0.5 \text { to } 10-15 \mathrm{~mm} \mathrm{Hg} \\
\text { target PCWP }\end{array}$ & $\begin{array}{l}\text { Vasopressin, endothelin-1, norepinephrine and 6- } \\
\text { keto-prostaglandin } \mathrm{F}_{1 \mathrm{a}} \text { decreased and } \mathrm{pH} \mathrm{H}_{\mathrm{i}} \\
\text { increased in HES } 200 / 0.5 \text { but not albumin group } \\
\text { ( } p<0.05 \text { for all comparisons); ANP increased by } \\
\text { albumin but not HES } 200 / 0.5 \text { ( } p<0.05 \text { ) }\end{array}$ \\
\hline Boldt et al., 1998 [49] & 150 & Postoperative sepsis & $\begin{array}{l}20 \% \text { albumin vs } 10 \% \text { HES } \\
200 / 0.5 \text { to } 12-15 \mathrm{~mm} \mathrm{Hg} \\
\text { target PCWP }\end{array}$ & $\begin{array}{l}\mathrm{PaO}_{2} / \mathrm{FiO}_{2} \text { increased and lactate decreased by } \\
\mathrm{HES}_{2} 200 / 0.5 \text { but not albumin }(\mathrm{p}<0.05 \text { for both } \\
\text { comparisons); higher cardiac index, } \mathrm{DO}_{2} 2 \text { and } \\
\mathrm{VO}_{2} 1 \text { in } \mathrm{HES} 200 / 0.5 \text { group ( } \mathrm{p}<0.05 \text { for all } \\
\text { comparisons); no differences in incidence of renal } \\
\text { failure, platelet count, PT or aPTT }\end{array}$ \\
\hline Palumbo et al., 2006 [59] & 20 & Severe sepsis & $\begin{array}{l}20 \% \text { albumin vs } 6 \% \text { HES } \\
130 / 0.4\end{array}$ & $\begin{array}{l}\text { PCWP of } 15-18 \mathrm{~mm} \text { Hg successfully maintained } \\
\text { by both colloids throughout the } 5 \text {-day study } \\
\text { period; temperature, MAP, pulmonary artery } \\
\text { pressure, CVP, heart rate and urine output } \\
\text { remained stable in both groups; HES increased } \\
\text { cardiac index and several oxygenation parameters } \\
\text { and decreased APACHE II score }\end{array}$ \\
\hline
\end{tabular}

ANP, atrial natriuretic peptide; APACHE, Acute Physiology and Chronic Health Evaluation; aPTT, activated partial thromboplastin time; CVP, central venous pressure; $\mathrm{DO}_{2} \mathrm{l}$, oxygen delivery index; $\mathrm{HES}$, hydroxyethyl starch; $\mathrm{MAP}$, mean arterial pressure; $\mathrm{PaO}_{2} / \mathrm{FiO} \mathrm{F}_{2}$, ratio of partial pressure of arterial oxygen to fraction of inspired oxygen; PCWP, pulmonary capillary wedge pressure; $\mathrm{pH}_{\mathrm{i}}$, gastric intramucosal $\mathrm{pH}$; $\mathrm{PT}$, prothrombin time; RVEF, right ventricular ejection fraction; sELAM-1, soluble endothelial leukocyte adhesion molecule-1; sICAM-1, soluble intercellular adhesion molecule-1; SVRI, systemic vascular resistance index; $\mathrm{VO}_{2}$ l, oxygen consumption index.

developing spontaneous bacterial peritonitis, hyperoncotic albumin diminished the incidence of renal impairment [53]. Unlike HES 200/0.5 (molecular weight/molar substitution ratio), hyperoncotic albumin improved circulatory function of patients with spontaneous bacterial peritonitis [58].

\section{High-risk neonates}

In randomized trials of high-risk premature infants (Table 3 ), hyperoncotic albumin reduced the frequency of illnesses, lessened whole body edema and improved respiratory function $[35,42]$. Apgar scores were higher, the frequency of cerebral edema lower and hospital stay shorter after hyperoncotic albumin administration in newborns with asphyxia and brain edema [56].

\section{Brain injury}

Hyperoncotic albumin reduced disability at 3 months in patients with acute ischemic stroke and normal hematocrit (Table 3) [40]. Use of hyperoncotic albumin to maintain high oncotic pressure also led to more favorable outcomes in a randomized trial of patients with closed head injury [43]. All patients receiving high-oncotic-pressure therapy recovered with minimal or no neurological deficit, whereas $30 \%$ of the control group remained in a vegetative state or died.

\section{Intradialytic hypotension}

In two randomized crossover trials (Table 3), hyperoncotic albumin was more effective than either saline [54] or hypertonic saline [55] in averting blood volume declines. Systolic hypotension was also reduced by hyperoncotic albumin compared with saline [55]. 
Critical Care Vol 12 No 2 Jacob et al.

Table 3

Randomized clinical trials of hyperoncotic albumin in other indications

\begin{tabular}{llll}
\hline Trial & $\mathbf{n}$ & Indication & Regimen \\
\hline Liver disease & & & \\
Gentilini et al., $1999[51]$ & 126 & $\begin{array}{l}\text { Cirrhosis and refractory } \\
\text { ascites }\end{array}$ & $\begin{array}{l}\text { Inpatient treatment with } \\
12.5 \mathrm{~g} / \text { day } 25 \% \text { albumin } \\
\text { plus diuretics vs diuretics } \\
\text { alone }\end{array}$
\end{tabular}

Sort et al., 1999 [53]

Fernández et al., 2005 [58]

20 Cirrhosis and spontaneous bacterial peritonitis

126 Cirrhosis with ascites and spontaneous bacterial peritonitis
$1.5 \mathrm{~g} / \mathrm{kg} \mathrm{20 \%}$ albumin within $6 \mathrm{~h}$ of diagnosis and $1 \mathrm{~g} / \mathrm{kg}$ on day 3 vs no albumin; intravenous cefotaxime in both groups

$20 \%$ albumin vs $6 \%$ HES 200/0.5, both administered at $1.5 \mathrm{~g} / \mathrm{kg}$ after baseline measurements and $1.0 \mathrm{~g} /$ $\mathrm{kg}$ on day 3

Results

$90.5 \%$ cumulative treatment response rate in group receiving albumin vs $74.7 \%$ in control group $(p<0.05)$; shorter hospital stay $(p<$ $0.05)$ in group receiving albumin (20 vs 24 days) resulting in 59\% cost savings; no survival difference

Renal impairment in 33\% of control group vs $10 \%$ of albumin recipients $(p=0.002) ; 29 \%$ hospital mortality in control group vs $10 \%$ of group receiving albumin $(p=0.01) ; 41 \%$ and $22 \%$ mortality, respectively, by 3 months of follow-up ( $p=0.03$ )

Albumin increased mean arterial pressure and decreased plasma renin activity; no improvements in circulatory function in patients receiving HES; 4 of $10 \mathrm{HES}$ recipients developed spontaneous bacterial peritonitis-induced circulatory dysfunction or renal failure, whereas neither complication occurred in any of the 10 patients receiving albumin

\section{High-risk neonates}

McMurray et al., 1948 [35]

Greenough et al., 1993 [42]

Gürkan et al., 2001 [56]

Brain injury

Goslinga et al., 1992 [40]

Tomita et al., 1994 [43]

18

Closed head injury

Intradialytic hypotension

van der Sande et al., 1999 [54] 10 Crossover trial of stable dialysis patients

van der Sande et al., 2000 [55] $9 \quad$ Crossover trial of cardiaccompromised dialysis patients
$3 \mathrm{ml} 25 \mathrm{~g} / \mathrm{dl}$ albumin injected per pound body weight $1-2$ times weekly vs no albumin

$5 \mathrm{ml} / \mathrm{kg} 20 \%$ albumin vs placebo

$0.5 \mathrm{~g} / \mathrm{kg} \mathrm{20 \%}$ albumin vs routine fluid

8.5 days shorter mean time to regain birth weight in infants receiving albumin $(p=0.02)$ and significantly fewer illnesses

Albumin reduced edema based on weight loss $(p<0.01)$, whereas control group gained weight $(\mathrm{p}<0.05) ; 27 \%$ reduction in inspired oxygen requirement after albumin treatment $(p<0.05)$ with no change in control group

Higher modified Apgar score in group receiving albumin after $24 h(p<0.001)$ with difference persisting 8 days; cerebral edema reduced in greater proportion of albumin than control group as judged by head ultrasound; $28 \%$ shorter hospital stay in albumin-treated group $(p<0.01)$

In subgroup with normal hematocrit

Normovolemic hemodilution with 20\% albumin vs crystalloids

High-oncotic-pressure therapy with $25 \%$ albumin and furosemide vs normaloncotic-pressure therapy

$20 \%$ albumin vs $10 \%$ HES $200 / 0.5$ vs saline, in conjunction with ultrafiltration and hemodialysis

$100 \mathrm{ml}$ of $20 \%$ albumin vs $10 \%$ HES $200 / 0.5$ vs $3 \%$ hypertonic saline, in conjunction with ultrafiltration and hemodialysis accounting for two-thirds of study population, mortality and disability at 3 months significantly lower among albumin recipients

Recovery with minimal or no neurological deficit in patients of high-oncotic-pressure therapy group; persistent vegetative state or death in 30\% of patients receiving normaloncotic-pressure therapy

Greater decrease in blood volume with saline than other fluids $(p<0.05)$

Greater intradialytic reductions in systolic blood pressure $(\mathrm{p}<0.05)$ and blood volume $(p<0.05)$ with hypertonic saline than either albumin or HES 
Table 3 (Continued)

Randomized clinical trials of hyperoncotic albumin in other indications

Nephrotic syndrome

Kosnadi et al., 1987 [38]

24

Children with nephrotic syndrome

Fliser et al., 1999 [50]

$\mathrm{Na}$ et al., 2001 [57]
9

Double-blind, placebocontrolled crossover trial in patients with nephrotic syndrome on standardized salt intake

7
Crossover trial in patients with nephrotic syndrome
$20 \%$ albumin + furosemide + prednisone vs human plasma + furosemide + prednisone vs prednisone alone

$200 \mathrm{ml} \mathrm{20 \%}$ albumin + $0.9 \% \mathrm{NaCl}$ sham infusion vs $200 \mathrm{ml} 20 \%$ albumin + $60 \mathrm{mg}$ furosemide vs 60 mg furosemide + sham infusion of $200 \mathrm{ml} \mathrm{H}_{2} \mathrm{O}$

$100 \mathrm{ml} 20 \%$ albumin vs $5 \%$ dextrose followed by $160 \mathrm{mg}$ of furosemide
Diuresis earlier with albumin + furosemide + prednisone vs prednisone alone $(p=0.011)$ and percent body weight loss greater $(p<$ 0.01 )

Urinary volume and sodium excretion higher by $20 \%(p<0.05$ and $p<0.01$, respectively) during first $8 \mathrm{~h}$ with albumin + furosemide than furosemide alone

Albumin potentiated the diuretic effect of furosemide

HES, hydroxyethyl starch.

\section{Nephrotic syndrome}

Hyperoncotic albumin was investigated in three randomized trials of nephrotic syndrome (Table 3). Hyperoncotic albumin with concomitant furosemide accelerated diuresis and promoted body weight loss [38]. In addition, hyperoncotic albumin potentiated both the diuretic and natriuretic effects of furosemide $[50,57]$.

\section{Survival}

Mortality data were available for 24 randomized comparisons. The median duration of follow-up was 5 days (IQR, 5 to 13 days). Three trials $[40,51,53]$ were specifically designed to assess survival as a primary study endpoint. No patient died in 4 of the 24 comparisons [37,39,41,56]. The remaining 20 comparisons with at least one death were included in a quantitative meta-analysis of survival (Figure 2). Total mortality in the 20 comparisons (Figure 2) was 266/1,287 (21\%). In the meta-analysis, there was no evidence of either heterogeneity $(p=0.86)$ or publication bias $(p=0.87)$. The observed statistical power of the meta-analysis was $98 \%$ to detect a $35 \%$ reduction in relative mortality risk by hyperoncotic albumin (RR 0.65 ) and $82 \%$ to demonstrate a $35 \%$ relative mortality risk increase (RR 1.35). No significant overall effect of hyperoncotic albumin on survival was detected (RR 0.95; Cl 0.78 to 1.17).

\section{Discussion}

This is the first systematic review exclusively focused on hyperoncotic albumin. With this focus, variability due to potential differences in the effects of 4 to $5 \%$ vs 20 to $25 \%$ albumin is eliminated.

The included randomized clinical trials supplied evidence of clinical benefits such as reduction in morbidity in high-risk neonates [35] and brain injury [40], avoidance of major organ edema in surgery [39] and high-risk neonates [56] and preservation of renal function in surgery [41] and liver disease [53]. These benefits in the randomized trials are consistent with extensive evidence from non-randomized clinical investigations, as discussed below.

\section{Limitations}

The included randomized trials addressed diverse clinical indications for hyperoncotic albumin, and the number of trials focusing on any single indication was, in most instances, relatively small. Within any particular indication, furthermore, no more than two trials evaluated clinically relevant endpoints of the same type. Consequently, firm conclusions about clinical benefit in defined indications are difficult to draw. Another limitation was the variety of control regimens. Treatment effects of hyperoncotic albumin might differ, for instance, in comparison to crystalloid vs colloid control fluid.

The available data in the categories of trauma and of sepsis were predominantly furnished by a single group of investigators, and 10 of the 11 randomized comparisons from this group were performed using the same trial design (Tables 1 and 2). The generalizability of those results is uncertain, and further trials are needed in those categories.

In the survival meta-analysis, the short median follow-up of 5 days may account partly or entirely for the lack of overall effect. Follow-up of $\mathbf{3 0}$ days or longer is typical for outcomes trials. Even at 30 days survival, differences may be substantially underestimated compared with those observed at 90 days [60]. In all three included trials designed to assess survival, the follow-up period was at least 90 days $[40,51,53]$.

As in previous systematic reviews of albumin administration $[26,27]$, one of the control regimens represented among the trials in this review was no albumin, accounting for six of the included trials (24\%). No albumin as the designated control regimen did not necessarily mean no volume expansion, however. In one surgery trial [36] the no-albumin control group received a cumulative mean volume of 24 I non-colloid fluids over the course of the 5-day study. In two trials of high-risk 


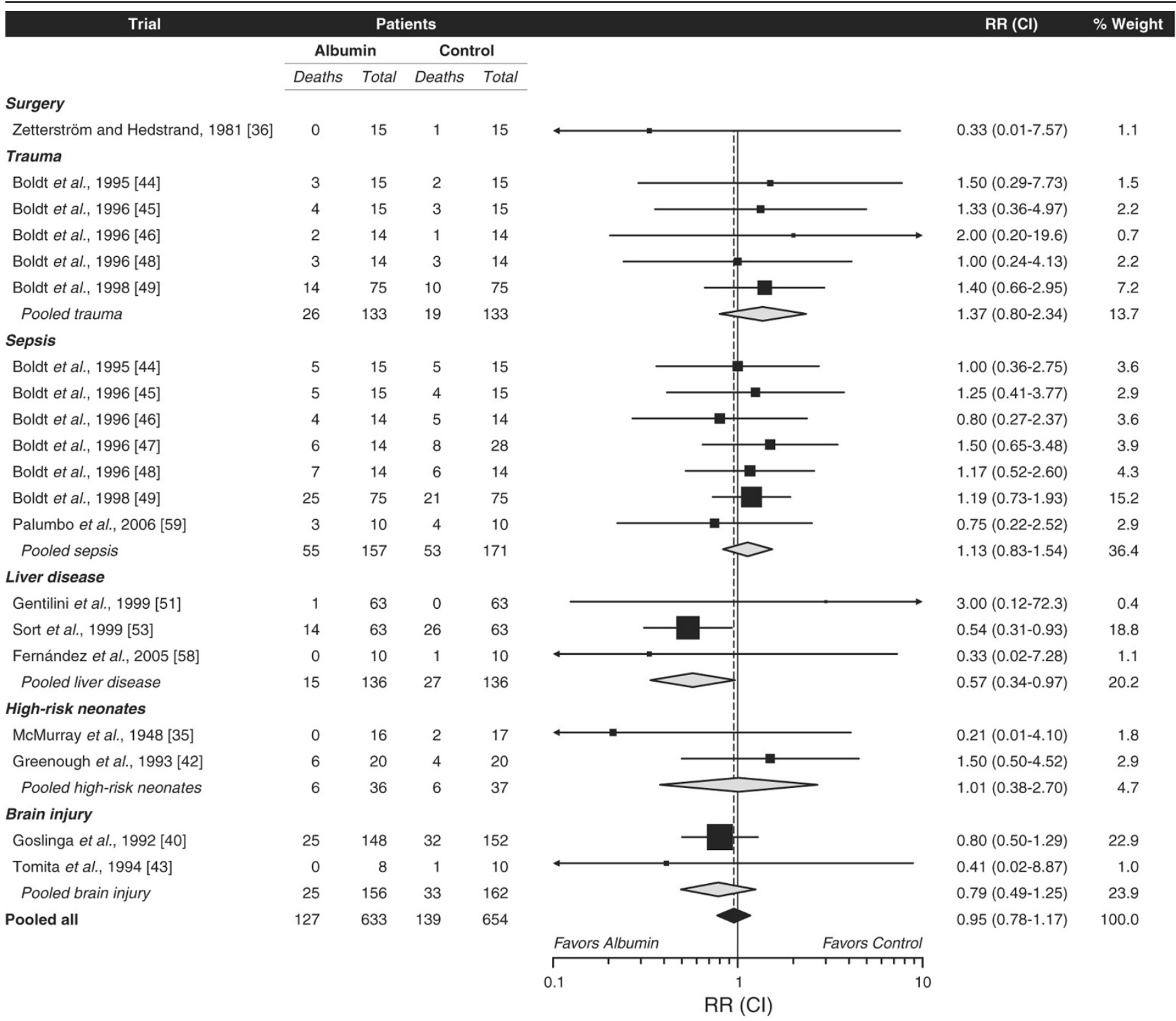

Quantitative meta-analysis of survival in hyperoncotic albumin compared with control group. Data points are scaled in proportion to meta-analytic weight. $\mathrm{Cl}, 95 \%$ confidence interval; $\mathrm{RR}$, relative risk.

neonates, the no albumin control regimen consisted of routine fluid [56] or $5 \mathrm{ml} / \mathrm{kg}$ infant maintenance fluid [42]. No albumin control group volume expansion, if any, in three other trials was unspecified $[35,51,53]$. If control patients in any of those three trials did not receive volume expanders, then observed differences between the hyperoncotic albumin and control arms might have reflected volume expansion rather than a specific effect of hyperoncotic albumin per se. In that scenario, it is possible that an alternative fluid could exert effects similar to those observed with hyperoncotic albumin.

These limitations highlight the need for further trials. There is consistent evidence that hyperoncotic albumin has the capacity to reduce edema; however, the impact of edema reduction on outcomes requires further investigation. Short follow-up has been a deficiency of most hyperoncotic albumin trials to date, and future trials with longer follow-up are essential to assess outcomes. Especially in the areas of surgery, trauma and sepsis existing data need to be supplemented by additional trials. Lastly, standardized and well-specified control regimens will be important in future trials so that clearer inferences can be drawn concerning the specific effects of hyperoncotic albumin vs those of particular alternative fluids or generic volume expansion.

\section{Small-volume resuscitation}

A small volume can be administered more rapidly, and so the period during which the patient remains at increased risk of 
poor outcome can be commensurately reduced. In the prehospital setting, hyperoncotic albumin could accelerate hemodynamic stabilization and transport to hospital. Another advantage in the pre-hospital setting is the portability of small hyperoncotic albumin volumes.

In surgical patients, small-volume hyperoncotic albumin resuscitation may simplify fluid management by maintaining a stable hemodynamic state. In a retrospective study of 28 patients undergoing pelvic exenterations for gynecological malignancies, recipients of $25 \%$ albumin required fewer boluses of fluid $(p<0.01)$, electrolyte $(p<0.01)$ and diuretic $(p<0.01)$ and could be started sooner on central hyperalimentation $(p<$ 0.05) than the group receiving crystalloid [61].

Speed of resuscitation may also be of the essence in rapidly progressing conditions such as spontaneous bacterial peritonitis [53] and in the urgent care of high-risk neonates [20]. In pre-term infants with respiratory distress syndrome, intravenous administration of $1 \mathrm{~g} / \mathrm{kg} \mathrm{25 \%}$ albumin over a $10 \mathrm{~min}$ period increased blood volume $(p<0.0005)$ and mean arterial blood pressure $(p<0.05)$ within $10 \mathrm{~min}$ after infusion was completed [20]. Albumin also significantly augmented glomerular filtration in that study, as indicated by increased creatinine clearance $(p<0.005)$.

\section{Edema}

Formation of edema serves as a harbinger of organ failure [62] and may, depending upon the tissues affected, lead to impairments in gas exchange, myocardial compliance, neurocognitive function, gut barrier competence, nutrient absorption and wound healing. Pulmonary edema, for instance, is associated with prolonged ventilator dependence and intensive care unit stay [63]. Furthermore, positive fluid balance appears to be predictive of poorer survival in sepsis [64]. Encephalopathy may occur at least as frequently as other forms of organ damage during sepsis [65]. Contributors to septic encephalopathy are reduced cerebral blood flow and oxygen extraction by the brain and cerebral edema [65]. While edema may be adequately tolerated by many patients, such as young serious trauma victims, more grave consequences may be faced by elderly or frail patients in whom edema may retard oxygen delivery to the lungs, myocardium and brain.

The impact of cerebral edema on outcome after subarachnoid hemorrhage $(\mathrm{SAH})$ was investigated in 374 patients [66]. In a multivariate analysis assessing 16 significant univariate predictors, cerebral edema demonstrated by computed tomography was an independent risk factor both for death (odds ratio 2.5; $\mathrm{Cl} 1.1$ to 5.6) and for either death or severe disability (odds ratio $2.5 ; \mathrm{Cl} 1.2$ to 5.4 ). Severe disability was defined as a modified Rankin scale score of $>3$. These observations support a causal role for cerebral edema in producing poor outcomes and prompted the investigators to conclude: 'Critical care management strategies that minimize edema forma- tion after SAH may improve outcome' [66]. Similarly, in a prospective study of 113 non-traumatic SAH patients evaluated by comprehensive neuropsychological testing at 3 months, cerebral edema was an independent risk factor for cognitive impairment [67].

Hyperoncotic albumin may be of particular clinical value in edematous states such as those encountered in liver disease, high-risk neonates, brain injury and nephrotic syndrome (Table 3). While edema may pose problems in sepsis as well, this review suggested advantages of HES over albumin in sepsis, e.g., higher cardiac index and oxygenation. However, follow-up in all the included sepsis trials was only 5 days. With follow-up of 30 days or longer HES has been shown in randomized trials to increase the incidence of acute renal failure among patients with severe sepsis or septic shock $[60,68]$. Hyperoncotic albumin displays protective effects on the kidney $[41,53]$ and hence would likely offer a safer fluid management alternative than HES in sepsis.

The randomized trial evidence showing the capacity of hyperoncotic albumin to reduce edema is supplemented by non-randomized clinical studies and animal models in the areas of high-risk neonates, brain injury and nephrotic syndrome. Among 10 normotensive premature infants with idiopathic respiratory distress syndrome, 20\% albumin reduced body weight $(p<0.01)$, indicating lessened edema, and improved urine output $(p<0.05)$ within 6 h [69].

Decreased cerebral edema after hyperoncotic albumin administration was shown in one included randomized trial [56]. Reduction in cerebral edema and other sequelae of brain injury by hyperoncotic albumin has also been repeatedly demonstrated in other studies. In a non-randomized trial of 22 patients with putaminal hemorrhage, 50 to $100 \mathrm{ml} /$ day of $25 \%$ albumin with concomitant furosemide significantly reduced brain edema as assessed by computed tomography [70]. No albumin recipient died or remained in a vegetative state compared with $27 \%$ of crystalloid recipients. In a cohort study of 10 patients with elevated intracranial pressure and brain edema, infusion of $2 \mathrm{~g} / \mathrm{kg} 25 \%$ albumin over $60 \mathrm{~min}$ produced a significant and long-lasting ( $\geq 9 \mathrm{~h}$ ) decline in intracerebral pressure [71]. Among hemorrhagic stroke patients, rapid infusion of $50 \mathrm{ml} 20 \%$ albumin promptly and significantly reversed electroencephalographic abnormalities [72]. The randomized, double-blinded, placebo-controlled multi-center Albumin in Acute Stroke (ALIAS) clinical trial funded by the US National Institutes with a target enrollment of 1,800 patients is evaluating the neuroprotective effects of $25 \%$ albumin as compared with saline [73].

According to experimental cerebral ischemia studies, hyperoncotic albumin can reduce infarct volume and edema, augment cortical perfusion and improve functional outcome [74,75]. In head trauma models, hyperoncotic albumin increased neuro- 
logical score and reduced brain tissue edema and damage [76-78].

All three included randomized trials in nephrotic syndrome $[38,50,57]$ indicated the ability of hyperoncotic to promote diuresis, and one of these trials [38] also provided direct evidence of edema reduction. In a non-randomized study of 14 severely edematous children with minimal change nephrotic syndrome, 20\% albumin infused at an albumin dose of $0.5 \mathrm{~g} /$ $\mathrm{kg}$ over $1 \mathrm{~h}$ followed by furosemide reduced pretibial edema and body weight within $1 \mathrm{~h}(\mathrm{p}<0.05)$ [79]. These effects persisted for at least $24 \mathrm{~h}(\mathrm{p}<0.005)$.

\section{Anti-inflammatory activity}

Starling forces may be sufficient to explain the effectiveness of hyperoncotic albumin for small-volume resuscitation and edema reduction. However, additional mechanisms such as anti-inflammatory and antioxidant activity may contribute to the clinical benefits of hyperoncotic albumin. Furthermore, at least some of these mechanisms are specific to hyperoncotic rather than 4 to $5 \%$ albumin. Thus, in an in vitro study of blood specimens from 10 healthy adult human volunteers, dilution with HES 450/0.7 produced a dose-dependent increase in neutrophil activation to 19 -fold the baseline level [80]. The increase after dilution with various crystalloids was to 13- to 19 -fold the baseline level and with $5 \%$ albumin twofold. In contrast, there was no evidence of neutrophil activation by $25 \%$ albumin.

\section{Antioxidant effects}

The reduced thiol moiety on cysteine 34 of albumin can play a direct antioxidant role. In a randomized clinical trial of 20 patients with acute lung injury due to trauma, pneumonia, sepsis and other insults, repeated administration of $25 \%$ albumin elevated plasma thiol concentration $(p=0.0001)$ and total antioxidant capacity $(p=0.033)$ compared with saline placebo [81].

\section{Safety}

The capacity of hyperoncotic albumin to shift fluid from the interstitium to the intravascular space may be viewed as a twoedged sword, depending upon the hydration state of the patient. In edematous states, such fluid shifts may be desirable. Conversely, hyperoncotic albumin should probably be avoided in patients with severe dehydration [3].

High doses of hyperoncotic albumin could potentially increase pulmonary edema and capillary leak. In one widely cited randomized trial of Lucas et al. [82], patients receiving very high hyperoncotic albumin doses $(1,142 \mathrm{~g})$ and total fluid volumes $(44.9$ l) displayed impairment in pulmonary function. Commentators have ascribed that result to fluid overload rather than hyperoncotic albumin per se, however [83,84]. The trial of Lucas et al. was not included in the present review because albumin was administered with the aim of elevating serum albumin concentration rather than expanding intravascular volume, and indeed the attained central venous pressure (mean $18.6 \mathrm{~cm} \mathrm{H}_{2} \mathrm{O}$ ) was supranormal.

In a dose-escalation study of 25\% albumin treatment in 82 patients with acute ischemic stroke, mild or moderate pulmonary edema was observed in $13 \%$ of the patients [85]. This adverse effect was readily managed with diuretics, and $25 \%$ albumin doses up to $2 \mathrm{~g} / \mathrm{kg}$ could be tolerated without major dose-limiting complications.

None of the trials included in the present review or in a prior systematic review of both hyperoncotic and 4 to $5 \%$ albumin [28] has indicated harmful effects attributable to albumin. A Cochrane meta-analysis encompassing both 4 to $5 \%$ and 20 to $25 \%$ solutions suggested increased mortality among albumin recipients (RR 1.7) [26]. That finding could not be replicated either in the SAFE trial [25] or a more comprehensive subsequent meta-analysis [27]. In the present survival metaanalysis, which was adequately powered to detect a relative mortality risk increase only half as great as that reported by the Cochrane investigators, there was no evidence of poorer survival among hyperoncotic albumin recipients.

\section{Conclusion}

Small-volume resuscitation with hyperoncotic albumin can speed the stabilization of the patient and alleviate potentially harmful edema. Nevertheless, the clinical benefits of hyperoncotic albumin remain incompletely characterized. Further trials are needed, especially in the areas of surgery, trauma and sepsis.

\section{Key messages \\ Hyperoncotic 20 to $25 \%$ albumin solutions are suitable for small-volume resuscitation. \\ In a systematic review of 25 randomized clinical trials, sev- eral benefits of hyperoncotic albumin were documented such as decreases in morbidity, renal impairment and edema.}

There was no evidence of deleterious effects due to hyperoncotic albumin.

Overall survival was not affected by hyperoncotic albumin (pooled relative risk, $0.95 ; 95 \%$ confidence interval 0.78-1.17).

Further clinical trials of hyperoncotic albumin are warranted.

\section{Competing interests}

The Clinic of Anesthesiology, Ludwig-Maximilians University Munich, Munich, Germany, with which MJ, DC, PC and MR are affiliated, was the recipient of an unrestricted research grant from CSL Behring, Marburg, Germany supporting investigations of interactions between colloids and the endothelial gly- 
cocalyx. That work resulted in three original contributions. The grant was not linked to any specific research goals or to manuscript approval by CSL Behring. MJ has received lecture honoraria from B. Braun, Melsungen, Germany and Fresenius Kabi, Bad Homburg, Germany. MMW has received past unrestricted research grant support from CSL Behring and, prior to 2003, the Plasma Protein Therapeutics Association, Annapolis, Maryland, USA. BFB has no competing interests to declare.

\section{Authors' contributions}

All authors participated in the design of the study. MJ, MMW and MR extracted data and drafted the manuscript. All authors revised the article and read and approved the final manuscript.

\section{Acknowledgements}

This investigation was conducted and reported solely by the authors. No other individual or organization contributed substantially to the conception or design of the study, acquisition, analysis and interpretation of data, or manuscript preparation and revision. No essential materials for the investigation were furnished by any individual or organization other than the authors.

The conduct and reporting of this investigation, including preparation of the manuscript, were sponsored through an unrestricted grant from CSL Behring, Marburg, Germany. The study sponsor played no role in study design, in the collection, analysis, and interpretation of data, in the writing and revising of the manuscript, or in the decision to submit the manuscript for publication.

\section{References}

1. Kreimeier U, Peter K, Meßmer K: Small volume - large benefit? Anaesthesist 2001, 50:442-449.

2. Bruegger D, Bauer A, Rehm M, Niklas $M$, Jacob M, Irlbeck $M$, Becker BF, Christ F: Effect of hypertonic saline dextran on acidbase balance in patients undergoing surgery of abdominal aortic aneurysm. Crit Care Med 2005, 33:556-563.

3. Heyl JT, Janeway CA: The use of human albumin in military medicine. Part I. The theoretical and experimental basis for its use. US Navy Med Bull 1942, 40:785-791.

4. Lamke LO, Liljedahl SO: Plasma volume expansion after infusion of $5 \%, 20 \%$ and $25 \%$ albumin solutions in patients. Resuscitation 1976, 5:85-92.

5. Lazrove S, Waxman K, Shippy C, Shoemaker WC: Hemodynamic, blood volume, and oxygen transport responses to albumin and hydroxyethyl starch infusions in critically ill postoperative patients. Crit Care Med 1980, 8:302-306.

6. Baron J-F, de Kegel D, Prost AC, Mundler O, Arthaud M, Basset G, Maistre G, Masson F, Carayon A, Landault C, Barré E, Viars P: Low molecular weight hydroxyethyl starch $6 \%$ compared to albumin 4\% during intentional hemodilution. Intensive Care Med 1991, 17:141-148.

7. Haller M, Brechtelsbauer $\mathrm{H}$, Akbulut $\mathrm{C}$, Fett W, Briegel J, Finsterer $\mathrm{U}$ : Isovolemic hemodilution alters the ratio of whole-body to large-vessel hematocrit (F-cell ratio). A prospective, randomized study comparing the volume effects of hydroxyethyl starch 200,000/0.62 and albumin. Infusionsther Transfusionsmed 1995, 22:74-80.

8. Payen JF, Vuillez JP, Geoffray B, Lafond JL, Comet M, Stieglitz P, Jacquot C: Effects of preoperative intentional hemodilution on the extravasation rate of albumin and fluid. Crit Care Med 1997, 25:243-248.

9. Riddez L, Hahn RG, Brismar B, Strandberg A, Svensén C, Hedenstierna G: Central and regional hemodynamics during acute hypovolemia and volume substitution in volunteers. Crit Care Med 1997, 25:635-640.
10. Ernest D, Belzberg AS, Dodek PM: Distribution of normal saline and $5 \%$ albumin infusions in septic patients. Crit Care Med 1999, 27:46-50.

11. Rehm M, Orth V, Kreimeier $U$, Thiel $M$, Haller M, Brechtelsbauer $H$, Finsterer $\mathrm{U}$ : Changes in intravascular volume during acute normovolemic hemodilution and intraoperative retransfusion in patients with radical hysterectomy. Anesthesiology 2000, 92:657-664.

12. Ernest $D$, Belzberg AS, Dodek PM: Distribution of normal saline and $5 \%$ albumin infusions in cardiac surgical patients. Crit Care Med 2001, 29:2299-2302.

13. Rehm M, Haller M, Orth V, Kreimeier U, Jacob M, Dressel H, Mayer $\mathrm{S}$, Brechtelsbauer $\mathrm{H}$, Finsterer $\mathrm{U}$ : Changes in blood volume and hematocrit during acute preoperative volume loading with $5 \%$ albumin or $6 \%$ hetastarch solutions in patients before radical hysterectomy. Anesthesiology 2001, 95:849-856.

14. Rehm M, Orth VH, Kreimeier U, Thiel M, Mayer S, Brechtelsbauer $\mathrm{H}$, Finsterer $\mathrm{U}$ : Veränderungen des Blutvolumens während akuter normovolämer Hämodilution mit $5 \%$ Albumin und $6 \%$ Hydroxyethylstärke und intraoperativer Retransfusion. Anaes thesist 2001, 50:569-579.

15. Hedin A, Hahn RG: Volume expansion and plasma protein clearance during intravenous infusion of $5 \%$ albumin and autologous plasma. Clin Sci (Lond) 2005, 108:217-224.

16. Karanko MS, Laaksonen VO, Meretoja OA: Effects of concentrated albumin treatment after aortocoronary bypass surgery. Crit Care Med 1987, 15:737-742.

17. Bignall S, Bailey PC, Bass CA, Cramb R, Rivers RP, Wadsworth J: The cardiovascular and oncotic effects of albumin infusion in premature infants. Early Hum Dev 1989, 20:191-201.

18. Margarson MP, Soni NC: Changes in serum albumin concentration and volume expanding effects following a bolus of albumin 20\% in septic patients. Br J Anaesth 2004, 92:821-826.

19. Elman R, Kelly FJ, Simonsen DH: Pure serum albumin compared with citrated plasma in the therapy of chronic hypoalbuminemia. Ann Surg 1948, 128:195-209.

20. Lay KS, Bancalari E, Malkus H, Baker R, Strauss J: Acute effects of albumin infusion on blood volume and renal function in premature infants with respiratory distress syndrome. J Pediatr 1980, 97:619-623.

21. Hubbard RW, Matthew WT, Horstman D, Francesconi R, Mager $M$, Sawka MN: Albumin-induced plasma volume expansion: diurnal and temperature effects. J Appl Physiol 1984, 56:1361-1368.

22. Shah DM, Browner BD, Dutton RE, Newell JC, Powers SR Jr: Cardiac output and pulmonary wedge pressure. Use for evaluation of fluid replacement in trauma patients. Arch Surg 1977, 112:1161-1168.

23. Starling $\mathrm{EH}$ : On the absorption of fluids from connective tissue spaces. J Physiol (Lond) 1896, 19:312-326.

24. Holbeck S, Grände PO: Effects on capillary fluid permeability and fluid exchange of albumin, dextran, gelatin, and hydroxyethyl starch in cat skeletal muscle. Crit Care Med 2000, 28:1089-1095.

25. SAFE Study Investigators: A comparison of albumin and saline for fluid resuscitation in the intensive care unit. $N$ Engl J Med 2004, 350:2247-2256.

26. Cochrane Injuries Group Albumin Reviewers: Human albumin administration in critically ill patients: systematic review of randomised controlled trials. BMJ 1998, 317:235-240.

27. Wilkes MM, Navickis RJ: Patient survival after human albumin administration: a meta-analysis of randomized, controlled trials. Ann Intern Med 2001, 135:149-164.

28. Haynes GR, Navickis RJ, Wilkes MM: Albumin administration what is the evidence of clinical benefit? A systematic review of randomized controlled trials. Eur J Anaesthesiol 2003, 20:771-793.

29. Vincent JL, Dubois MJ, Navickis RJ, Wilkes MM: Hypoalbuminemia in acute illness: is there a rationale for intervention? A meta-analysis of cohort studies and controlled trials. Ann Surg 2003, 237:319-334.

30. Vincent $\mathrm{JL}$, Navickis RJ, Wilkes MM: Morbidity in hospitalized patients receiving human albumin: a meta-analysis of randomized, controlled trials. Crit Care Med 2004, 32:2029-2038.

31. Vincent JL, Sakr Y, Reinhart K, Sprung CL, Gerlach H, Ranieri VM: Is albumin administration in the acutely ill associated with 
increased mortality? Results of the SOAP study. Crit Care 2005, 9:R745-754.

32. Schulz KF, Chalmers I, Hayes RJ, Altman DG: Empirical evidence of bias. Dimensions of methodological quality associated with estimates of treatment effects in controlled trials. JAMA 1995, 273:408-412.

33. Egger M, Davey Smith G, Schneider M, Minder C: Bias in metaanalysis detected by a simple, graphical test. BMJ 1997, 315:629-634.

34. Cohn LD, Becker BJ: How meta-analysis increases statistical power. Psychol Methods 2003, 8:243-253.

35. McMurray L-G, Roe JH, Sweet LK: Plasma protein studies on normal newborn and premature infants. I. Plasma protein values for normal full term and normal premature infants; II. Use of concentrated normal human serum albumin in treatment of premature infants. Am J Dis Child 1948, 75:265-278.

36. Zetterström $\mathrm{H}$, Hedstrand U: Albumin treatment following major surgery. I. Effects on plasma oncotic pressure, renal function and peripheral oedema. Acta Anaesthesiol Scand 1981, 25:125-132.

37. Boldt J, von Bormann B, Kling D, Borner U, Mulch J, Hempelmann G: Volumenersatz mit einem neuen HydroxyäthylstärkePräparat (3\% HÄS 200/0,5) in der Herzchirurgie. Infusionsther Klin Ernahr 1986, 13:145-151.

38. Kosnadi LK, Rochmanadji R, Soemantri AG, Sastrosubroto H: Therapeutic use of albumin in nephrotic syndrome. Paediatr Indones 1987, 27:131-141.

39. Prien T, Backhaus N, Pelster F, Pircher W, Bünte $H$, Lawin P: Effect of intraoperative fluid administration and colloid osmotic pressure on the formation of intestinal edema during gastrointestinal surgery. J Clin Anesth 1990, 2:317-323.

40. Goslinga $\mathrm{H}$, Eijzenbach V, Heuvelmans $\mathrm{JH}$, van der Laan de Vries E, Melis VM, Schmid-Schönbein H, Bezemer PD: Custom-tailored hemodilution with albumin and crystalloids in acute ischemic stroke. Stroke 1992, 23:181-188.

41. Boldt J, Knothe C, Schindler E, Hammermann H, Dapper F, Hempelmann G: Volume replacement with hydroxyethyl starch solution in children. Br J Anaesth 1993, 70:661-665.

42. Greenough A, Emery E, Hird MF, Gamsu HR: Randomised controlled trial of albumin infusion in ill preterm infants. Eur $J$ Pediatr 1993, 152:157-159.

43. Tomita $\mathrm{H}$, Ito $\mathrm{U}$, Tone $\mathrm{O}$, Masaoka $\mathrm{H}$, Tominaga B: High colloid oncotic therapy for contusional brain edema. Acta Neurochir Supp/ 1994, 60:547-549.

44. Boldt J, Heesen M, Welters I, Padberg W, Martin K, Hempelmann G: Does the type of volume therapy influence endothelialrelated coagulation in the critically ill? $\mathrm{Br} J$ Anaesth 1995, 75:740-746.

45. Boldt J, Heesen M, Müller M, Pabsdorf M, Hempelmann G: The effects of albumin versus hydroxyethyl starch solution on cardiorespiratory and circulatory variables in critically ill patients. Anesth Analg 1996, 83:254-261.

46. Boldt J, Müller M, Heesen M, Heyn O, Hempelmann G: Influence of different volume therapies on platelet function in the critically ill. Intensive Care Med 1996, 22:1075-1081.

47. Boldt J, Müller M, Heesen M, Neumann K, Hempelmann GG: Influence of different volume therapies and pentoxifylline infusion on circulating soluble adhesion molecules in critically ill patients. Crit Care Med 1996, 24:385-391.

48. Boldt J, Mueller M, Menges T, Papsdorf M, Hempelmann G: Influence of different volume therapy regimens on regulators of the circulation in the critically ill. $\mathrm{Br} J$ Anaesth 1996, 77:480-487.

49. Boldt J, Müller M, Mentges D, Papsdorf M, Hempelmann G: Volume therapy in the critically ill: is there a difference? Intensive Care Med 1998, 24:28-36.

50. Fliser D, Zurbruggen I, Mutschler E, Bischoff I, Nussberger J, Franek E, Ritz E: Coadministration of albumin and furosemide in patients with the nephrotic syndrome. Kidney Int 1999, 55:629-634.

51. Gentilini P, Casini-Raggi V, Di Fiore G, Romanelli RG, Buzzelli G, Pinzani M, La Villa G, Laffi G: Albumin improves the response to diuretics in patients with cirrhosis and ascites: results of a randomized, controlled trial. J Hepatol 1999, 30:639-645.

52. Magder S, Lagonidis D: Effectiveness of albumin versus normal saline as a test of volume responsiveness in post-cardiac surgery patients. J Crit Care 1999, 14:164-171.
53. Sort $P$, Navasa $M$, Arroyo $V$, Aldeguer $X$, Planas $R$, Ruiz-del-Arbol L, Castells L, Vargas V, Soriano G, Guevara M, Ginès P, Rodés J: Effect of intravenous albumin on renal impairment and mortality in patients with cirrhosis and spontaneous bacterial peritonitis. N Engl J Med 1999, 341:403-409.

54. van der Sande FM, Kooman JP, Barendregt JN, Nieman FH, Leunissen KM: Effect of intravenous saline, albumin, or hydroxyethylstarch on blood volume during combined ultrafiltration and hemodialysis. J Am Soc Nephrol 1999, 10:1303-1308.

55. van der Sande FM, Luik AJ, Kooman JP, Verstappen V, Leunissen $\mathrm{KM}$ : Effect of intravenous fluids on blood pressure course during hemodialysis in hypotensive-prone patients. J Am Soc Nephro/ 2000, 11:550-555.

56. Gürkan F, Haspolat K, Yaramis A, Ece A: Beneficial effect of human albumin on neonatal cerebral edema. Am J Ther 2001 8:253-254.

57. Na KY, Han JS, Kim YS, Ahn C, Kim S, Lee JS, Bae KS, Jang IJ, Shin SG, Huh W, Jeon US: Does albumin preinfusion potentiate diuretic action of furosemide in patients with nephrotic syndrome? J Korean Med Sci 2001, 16:448-454.

58. Fernández J, Monteagudo J, Bargallo X, Jiménez W, Bosch J, Arroyo V, Navasa M: A randomized unblinded pilot study comparing albumin versus hydroxyethyl starch in spontaneous bacterial peritonitis. Hepatology 2005, 42:627-634.

59. Palumbo D, Servillo G, D'Amato L, Volpe ML, Capogrosso G, De Robertis E, Piazza O, Tufano R: The effects of hydroxyethyl starch solution in critically ill patients. Minerva Anestesiol 2006, 72:655-664.

60. Brunkhorst FM, Engel C, Bloos F, Meier-Hellmann A, Ragaller M, Weiler N, Moerer O, Gruendling M, Oppert M, Grond S, Olthoff D, Jaschinski U, John S, Rossaint R, Welte T, Schaefer M, Kern P, Kuhnt E, Kiehntopf M, Hartog C, Natanson C, Loeffler M, Reinhart $\mathrm{K}$ : Intensive insulin therapy and pentastarch resuscitation in severe sepsis. The German Competence Network Sepsis (SepNet). N Engl J Med 2008, 358:125-139.

61. Fiorica JV, Roberts WS, Hoffman MS, Barton DP, Finan MA, Lyman G, Cavanagh D: Concentrated albumin infusion as an aid to postoperative recovery after pelvic exenteration. Gynecol Oncol 1991, 43:265-269.

62. Nieuwenhuiizen GA, Knapen MF, Oyen WJ, Hendriks T, Corstens $\mathrm{FH}$, Goris $\mathrm{RJ}$ : Organ damage is preceded by changes in protein extravasation in an experimental model of multiple organ dysfunction syndrome. Shock 1997, 7:98-104.

63. Mitchell JP, Schuller D, Calandrino FS, Schuster DP: Improved outcome based on fluid management in critically ill patients requiring pulmonary artery catheterization. Am Rev Respir Dis 1992, 145:990-998.

64. Alsous $F$, Khamiees M, DeGirolamo A, Amoateng-Adjepong $Y$, Manthous CA: Negative fluid balance predicts survival in patients with septic shock: a retrospective pilot study. Chest 2000, 117:1749-1754.

65. Papadopoulos MC, Davies DC, Moss RF, Tighe D, Bennett ED: Pathophysiology of septic encephalopathy: a review. Crit Care Med 2000, 28:3019-3024.

66. Claassen J, Carhuapoma JR, Kreiter KT, Du EY, Connolly ES, Mayer SA: Global cerebral edema after subarachnoid hemorrhage: frequency, predictors, and impact on outcome. Stroke 2002, 33:1225-1232.

67. Kreiter KT, Copeland D, Bernardini GL, Bates JE, Peery S, Claassen J, Du YE, Stern Y, Connolly ES, Mayer SA: Predictors of cognitive dysfunction after subarachnoid hemorrhage. Stroke 2002, 33:200-208.

68. Schortgen F, Lacherade JC, Bruneel F, Cattaneo I, Hemery F, Lemaire $F$, Brochard L: Effects of hydroxyethylstarch and gelatin on renal function in severe sepsis: a multicentre randomised study. Lancet 2001, 357:911-916.

69. Greenough A, Greenall F, Gamsu HR: Immediate effects of albumin infusion in ill premature neonates. Arch Dis Child 1988, 63:307-309.

70. Tone $\mathrm{O}$, Ito $\mathrm{U}$, Tomita $\mathrm{H}$, Masaoka $\mathrm{H}$, Tominaga B: High colloid oncotic therapy for brain edema with cerebral hemorrhage. Acta Neurochir Suppl 1994, 60:568-570.

71. Miyasaka Y, Nakayama K, Matsumori K, Beppu T, Tanabe T, Kitahara T, Saito T: Albumin therapy for patients with increased intracranial pressure: oncotic therapy. No Shinkei Geka 1983, 11:947-954. 
72. Huang Z, Dong W, Yan $Y, X$ iao Q, Man Y: Effects of intravenous human albumin and furosemide on EEG recordings in patients with intracerebral hemorrhage. Clin Neurophysiol 2002, 113:454-458.

73. Ginsberg MD, Palesch YY, Hill MD: The ALIAS (ALbumin In Acute Stroke) Phase III randomized multicentre clinical trial: design and progress report. Biochem Soc Trans 2006, 34:1323-1326.

74. Huh PW, Belayev L, Zhao W, Busto R, Saul I, Ginsberg MD: The effect of high-dose albumin therapy on local cerebral perfusion after transient focal cerebral ischemia in rats. Brain Res 1998, 804:105-113.

75. Remmers M, Schmidt-Kastner R, Belayev L, Lin B, Busto R, Ginsberg MD: Protein extravasation and cellular uptake after highdose human-albumin treatment of transient focal cerebral ischemia in rats. Brain Res 1999, 827:237-242.

76. Albright AL, Latchaw RE, Robinson AG: Intracranial and systemic effects of osmotic and oncotic therapy in experimental cerebral edema. J Neurosurg 1984, 60:481-489.

77. Belayev L, Alonso OF, Huh PW, Zhao W, Busto R, Ginsberg MD: Posttreatment with high-dose albumin reduces histopathological damage and improves neurological deficit following fluid percussion brain injury in rats. J Neurotrauma 1999, 16:445-453.

78. Chorny I, Bsorai R, Artru AA, Talmor D, Benkoviz V, Roytblat L, Shapira Y: Albumin or hetastarch improves neurological outcome and decreases volume of brain tissue necrosis but not brain edema following closed-head trauma in rats. I Neurosurg Anesthesiol 1999, 11:273-281.

79. Bircan Z, Kervancioglu M, Katar S, Vitrinel A: Does albumin and furosemide therapy affect plasma volume in nephrotic children? Pediatr Nephrol 2001, 16:497-499.

80. Rhee $P$, Wang D, Ruff $P$, Austin $B$, DeBraux $S$, Wolcott $K$, Burris $D$, Ling G, Sun L: Human neutrophil activation and increased adhesion by various resuscitation fluids. Crit Care Med 2000, 28:74-78.

81. Quinlan GJ, Mumby S, Martin GS, Bernard GR, Gutteridge JM, Evans TW: Albumin influences total plasma antioxidant capacity favorably in patients with acute lung injury. Crit Care Med 2004, 32:755-759.

82. Lucas CE, Ledgerwood AM, Higgins RF, Weaver DW: Impaired pulmonary function after albumin resuscitation from shock. $J$ Trauma 1980, 20:446-451.

83. Webb AR: The appropriate role of colloids in managing fluid imbalance: a critical review of recent meta-analytic findings. Crit Care 2000, 4(Suppl 2):S26-32.

84. Horsey P: Albumin and hypovolaemia: is the Cochrane evidence to be trusted? Lancet 2002, 359:70-72.

85. Ginsberg MD, Hill MD, Palesch YY, Ryckborst KJ, Tamariz D: The ALIAS Pilot Trial: a dose-escalation and safety study of albumin therapy for acute ischemic stroke - I: Physiological responses and safety results. Stroke 2006, 37:2100-2106. 